\title{
The Civil War's Forgotten Transatlantic Tariff Debate and the Confederacy's Free Trade Diplomacy
}

As southern states steadily seceded in the first months of 1861, the British press speculated that the Morrill Tariff's passage was an underlying cause of secession, or at least a barrier to reunion. Contemporaries on both sides of the Atlantic were well aware that the tariff would greatly affect European diplomacy with both North and South, to the former's detriment and the latter's favor.

The Union's Morrill Tariff, which Henry C. Carey, the "Ajax of protectionism," influenced and lobbied for, contrasted sharply with the South's free trade advocacy. The Morrill Tariff had been an important component of the 1860 Republican platform, which ended up a tentative triumph for the party's Whig faction, as it also called for internal improvements, a Pacific railroad, and a homestead law. ${ }^{1}$ The British, in turn, viewed the protective tariff with great trepidation, as it threatened British manufactures and proved antithetical to a subject about which, as English statesman Richard Cobden pointed out in December 1861, the British "are unanimous and fanatical"; that subject was free trade. ${ }^{2}$ By the time of the Civil War, free trade had become a national ideology in Britain. ${ }^{3}$

The Morrill Tariff's new levels of protection on specific items such as pig iron and wool severely hit at Britain's exports to its largest single market, the United States. ${ }^{4}$ The seceding southern states, providing England with nearly 80 percent of its raw cotton imports, alternatively offered Britain the promise of free trade. In Britain, the tariff thus played an integral role in justifying southern secession; developing Confederate trade policy; and affecting public opinion in England, Ireland, and Scotland concerning the causes of southern secession and the possibility of European recognition of the Confederacy. ${ }^{5}$ Over the course of the Civil War, the tariff sparked a contentious debate in Great Britain over southern motivations for secession. When the Union did not immediately declare itself on a crusade for abolition, some in Britain sympathized with the South. ${ }^{6}$ Northern sympathizers and antislavery advocates would afterward maintain that slavery had 
been the primary issue all along, while the Confederacy's transatlantic supporters and parts of the British press at first commonly portrayed the war as one fought between northern proponents of protection and southern advocates of free trade, a view that contemporary southerners and their British sympathizers made sure to encourage.

Recent studies of Civil War foreign relations have offered strong arguments for why Britain maintained its neutral stance throughout the conflict by emphasizing the strong transatlantic diplomatic and financial ties that had developed by the mid-nineteenth century. ${ }^{7}$ While persuasive, such studies have done so while overlooking British reaction to the tariff at the time it was passed. Although the Morrill Tariff may not have endangered British investment in the United States, it greatly ruffled Britain's commercial feathers and editorial pages. As Martin Crawford has observed, the tariff's impact on British opinion "was certainly greater than most modern historians have been willing to admit." Yet, aside from the recent work of Duncan Campbell, the tariff issue has become little more than a footnote within the diplomatic histories of the Civil War. ${ }^{9}$ The Civil War itself has received so much transatlantic study that the minimizing of the tariff issue is all the more striking. ${ }^{10}$ Brian Jenkins and Howard Jones have concluded that the Morrill Tariff did not help the Confederacy gain British support, and while David Crook, in his classic work The North, the South, and the Powers, briefly acknowledges that the South sought to "exploit British resentment at the Union's 'new protectionism,' symbolized by the Morrill tariff, and offered the lure of a free trade south as a vital new market for British goods" and that "southern propaganda excoriated the Morrill tariff," he offers no further treatment of these subjects. ${ }^{11}$ Granted, these studies accurately portray the tariff's small role in ultimately influencing the major decisions of Britain's top policymakers. If, however, the Confederacy's free trade diplomacy is expanded to include not only official state-to-state interactions but also the activities of non-state southern sympathizers and pro-Confederate propagandistic efforts to influence English public opinion, then the tariff debate takes on renewed significance within Civil War foreign relations.

A more thorough treatment of the transatlantic tariff debate is therefore sorely needed. A previous study of the English press during this period, for instance, has precipitously concluded that the Morrill Tariff "had little or no effect on forming editorial opinion," while Duncan Campbell's study of English public opinion suggests that few British journals "actually laid part of the blame for secession on the tariff" and that such blame was "unusual." ${ }^{2}$ This article demonstrates otherwise, while at the same time offering a fuller picture of Great Britain's reaction to the northern tariff 
by incorporating Scottish and Irish responses as well. Potential pitfalls invariably arise when discussing British "opinion." By drawing on a wide sampling of British news outlets, I am hopeful to have avoided some of these. ${ }^{13}$ With these caveats in mind, this article demonstrates that such British support for the South as existed went much further than support for self determination or opposition to fratricide, blockades, and democracy; it was also an opposition to northern protectionism.

What attention the tariff issue has received primarily revolves around defending or refuting Charles and Mary Beard's emphasis on domestic economic motivations for the Civil War's onset. ${ }^{14}$ Some viewed secession as little more than a replay of the Nullification Crisis of the early 1830s, wherein South Carolina had threatened secession as a response to protectionist legislation. As William Freehling has effectively argued, however, the tariff question and slavery agitation had already largely become "intermeshed" by the earlier crisis of nullification..$^{15}$ Furthermore, although the tariff issue was certainly raised in the secessionist conventions of South Carolina, Georgia, and Virginia, the topic was utterly overwhelmed by speeches concerning the perceived northern threat to the slave system practiced in the South and promised in the territories. A growing lack of southern cohesion on the tariff issue and the succession of seceding southern states in fact made the Morrill Tariff's passage possible, suggesting in hindsight at least that the tariff was by no means the primary motivating factor for secession. ${ }^{16}$ Nevertheless, many in Great Britain were not nearly so certain at the time of southern secession and the subsequent outbreak of civil war.

The Confederacy thereafter emphasized its desire for international free trade, dangling the carrot of free trade before Europe, even as it brandished King Cotton's stick. The Morrill Tariff's March 1861 passage was correspondingly used to obtain southern sympathy in Europe during the first years of the war. Tariff-centered speculation regarding southern secession proliferated among numerous British news outlets and drew a surprising amount of initial sympathy from within the zealous Victorian empire of free trade, as well as British editorial and parliamentary speculation as to the tariff's centrality to the conflict. ${ }^{17}$ Owing to its harmful effects upon British commerce and its unfriendly reception within the British press, the tariff thus helped influence Anglo-American relations for years to come.

While southern free trade diplomacy did not ultimately earn British recognition for the Confederacy any more than did the diplomacy of King Cotton, in the first years of the Civil War the northern tariff handily offered a rationale for secession that was politically palatable for many in 
free-trading Britain. Speculation regarding the tariff's possible economic and diplomatic consequences peppered the editorial pages of England, Ireland, and Scotland. Along with the northern blockade of the South, British recognition of southern belligerency in May 1861, the Trent Affair in November 1861, and the September 1862 Emancipation Proclamation, the South's free trade argument and transatlantic propaganda created ambiguity, division, confusion, and southern support across the Atlantic, and further exacerbated already tense Union-British relations, aided by the Union's initial refusal to tackle slavery. The South's governmental and nongovernmental allies made good use of the Confederacy's free trade diplomacy at the outset of the Civil War. The debate that followed the tariff's passage created heated British editorial and parliamentary speculation concerning the primary causes of southern secession, with some politicians and numerous newspapers suggesting part or all of the blame lay with northern protectionism, thereby contributing to the looming possibility of British recognition of the South in the first years of the war.

The Morrill Tariff Act passed the U.S. House of Representatives on May 10,1860 , on a sectional vote, with nearly all northern representatives in support and nearly all southern representatives in opposition. The bill was tabled in the Senate by Virginia's Robert Hunter-future Confederate secretary of state and author of the low 1857 tariff-until after the 1860 elections. ${ }^{18}$ While the bill hung in political limbo, its advocates and adversaries alike sprung into action. As Democratic senators attempted to further postpone a vote on the bill, president-elect Lincoln, who was himself "in favor of the internal improvement system, and a high protective tariff," promised a Pittsburgh audience that he would make sure that "no subject should engage your representatives more closely than the tariff . . . so that when the time for action arrives adequate protection can be extended to the coal and iron of Pennsylvania, the corn of Illinois, and the 'reapers of Chicago."'19

The tariff was welcomed in much of the North and generated a predictable outcry in much of the South..$^{20}$ Following the resignation of a number of southern senators who might otherwise have voted against the bill and successfully stopped its passage, the Senate Finance Committee was restructured, Rhode Island's James Fowler Simmons was made the committee's chair, and the Morrill Tariff passed on March 2, 1861. Democratic president James Buchanan, whose home state was the protectionist heartland of Pennsylvania, signed the bill into law with characteristic loyalty to his state. Ad valorem rates were raised from a low 17 percent to a modest average of 26 percent; but the tariff also contained specific protective duties approaching the high level of 50 percent or more on pig iron 
and cutlery, for instance, for the express purpose of protecting American "infant industries."

To both southerners dependent on foreign trade and British manufacturers, the bill appeared punitive, incendiary, and economically backward. The tariff quickly garnered British support for southern free trade. This was promptly clear to the London Times, which noted in late March 1861 that the South's goal was "to gain the goodwill of foreign nations, and particularly England, by placing Southern liberality in contrast with the grasping and narrow-minded legislation of the Free States. ... So far the game is still in favour of the new Confederacy."21

Across the Atlantic, southern secession initially received sympathy within the British press and public. The pro-North Liverpool Post recollected that "nearly all the aristocracy and a large portion of the middle classes were adverse to the North and in favor of the South.... Out of four or five hundred English newspapers, only five were bold enough openly to support the North.” John Lothrop Motley, an American in Britain, observed in a letter to his mother "a very great change in English sympathy" following the Morrill Tariff's passage, as it had "done more than any commissioners from the southern Republic could do to alienate the feelings of the English public towards the United States." ${ }^{22}$ In London, according to Confederate diplomat Edwin de Leon, the North at first had only received staunch support primarily from the radical Daily Neres and its evening counterpart the Star, John Bright's radical paper. De Leon even quoted antislavery advocate Henry Ward Beecher as saying at the war's outset that the clergy, Parliament, and merchants were against the North. With the exception of the labor classes, "all . . is anti-American," and studies have since shown that neither was British labor by any means unanimous in its support for the Union. ${ }^{23}$ Union minister to France, John Bigelow, having just arrived in London in September 1861, noted that "American Republicanism ... is right now very much out of fashion ... my country has few friends left her ... while the London press," with but two exceptions, "rejoices in our humiliation." Such sentiments were echoed by Charles Francis Adams Jr., who recalled with some exaggeration that the aristocracy, the press, and the middle class were all arrayed against the North. ${ }^{24}$ The New York Times also reported that the British had "entirely misapprehended the controversy," as they had arrived at the belief "that the question of Slavery does not constitute the essence of the quarrel; that it has been merely introduced as a blind, or as an instrument of provocation, and that the real point of contention lies in the national Tariff." ${ }^{25}$ The tariff argument had certainly found an accepting audience, further splitting British public opinion. 
In late February 1861, with the secession of six southern states and but a few weeks before the tariff's ultimate passage into law, Democratic congressman Daniel Sickles of New York decried the tariff's passage as it offered "the strongest provocation to England to precipitate recognition of the southern confederacy." The bill appeared to Sickles as "a disunion measure. It does as much as anything else to alienate the South from the Union. We all know that one of the questions that lie at the root of alienation between North and South is the protective policy of the North and the free-trade policy of the South," and the latter perceived that, now that the Republicans were in power, they intended to use that power "not only to assault their rights of property, but to tax them ... to enrich the manufacturing classes of the North." ${ }^{6}$ The pro-free trade Nerw York World acknowledged as well that the tariff "greatly disaffects England and France ... and presents them a direct inducement to recognize ... the independence of the states which reject both it and the policy on which it rests." ${ }^{27}$ The Nerw York Times similarly warned that, as Europe moved toward freer trade, the North's passage of this "ill-timed, ill-advised, and . . . disastrous measure" would put it "in conflict" with the Confederacy "in every court of Europe" and that it would seek recognition "by appealing to the popular sentiment in all commercial circles." ${ }^{28}$ Secession had by no means ended transatlantic opposition to the tariff and its potential impact upon domestic and foreign relations.

The London Annual Register of 1861 took the tariff's passage to mean that the North did not want to reunite with the Confederacy. ${ }^{29}$ The northern correspondent for London's Whig newspaper the Morning Chronicle in turn remarked on what he considered "an odd thing that all the material interests of England are arrayed on the side of the slave-holding South. They hold all the cotton; they alone sympathise with you on the doctrine of free-trade; they would be your largest customers if they got rid of the tariff ... which is only a bounty on the manufactures of the North.... England should begin to investigate the very important fact, where her true interests lie-whether with the manufacturing and commercial North, or the agricultural South?” The Morning Chronicle recognized that the bill was crafted to appeal to Pennsylvania voters but that it also "affords abundant evidence of what will be the policy of the Northern Union should one be formed, and offers also a marked contrast to the free-trade policy of the South."30

The Morning Chronicle went even further two weeks later. It noted that the tariff "has laid the first foundation of disunion and secession. ... The Southern revolution stands on two legs, not on one alone-free-trade and security of their slave property." The South had been unconstitutionally

40 JOURNAL OF THE CIVIL WAR ERA, VOLUME 3, ISSUE 1 
and "oppressively taxed ... for the benefit of Northern manufacturers.... This it is which has laid the first foundation of disunion and secession." Even though powerful commercial interests in New York and Boston were vocal in protesting against the Morrill Tariff, it nevertheless was going to pass. The Chronicle concluded that was not the moment for a protective tariff. "It will confirm the alienation of the South from the Union, at the same time that it will strengthen the motives of policy on the part of the Foreign Governments to recognize the free-trade Southern Confederacy." ${ }^{11}$ Scotland's Caledonian Mercury concurred; owing to the impact of the Morrill Tariff on their exports, the English, French, and Germans, "will have to fraternize with the South, notwithstanding its slave institutions." ${ }_{2}$ Within Great Britain's editorial pages, European recognition of the South appeared promising, owing to the latter's free trade diplomacy.

Less than a month before the bill was signed into law, the Confederacy's president, Jefferson Davis, had already played the free trade trump card in his inaugural address. He said that as "an agricultural people, whose chief interest is the export of a commodity required in every manufacturing country, our true policy is peace and the freest trade which our necessities permit." His speech also notably excluded any direct reference to slavery. ${ }^{33}$

Britons found Davis's inaugural address inscrutable-disseminated in the British press at about the same time as news arrived of the Morrill Tariff's passage-as was the South's "object" of secession. One contemporary study of English public opinion emphasized editorial confusion regarding the address: "Is it the question of slavery or that of free trade? We have never read a public document so difficult to interpret." Nevertheless, "the tendencies of trade are inexorable. It may be that the Southern population will now become our best customers." ${ }^{34}$ The conservative London Times approved of the Confederacy's internationalism but perceptively asked: "Is the question of Slavery subordinate to that of Free Trade, or is Free Trade the bribe offered to foreign nations to consideration of their pocketing their scruples about Slavery?"35 London's Once a Week remarked in mid-March that "of slavery there is not a word. This is an omission of some importance. It must be confessed at the same time that the Northern States have chosen a most awkward moment for . . bringing forward a High Protection Tariff, which . . . would shut up the States against the European manufacturer and producer." ${ }^{36}$

Abolitionist and free trade apostle Richard Cobden, though eventually a strong supporter of the Union, explained England's confusion to his longtime friend, Republican senator Charles Sumner: "There are two subjects on which we [the English] are unanimous and fanatical-personal freedom and Free Trade. . . . In your case we observe a mighty quarrel: 
on one side protectionists, on the other slave-owners. The protectionists say they do not seek to put down slavery. The slave-owners say they want Free Trade. Need you wonder at the confusion in John Bull's poor head?" ${ }^{37}$ Cobden thereafter frequently attacked the Northeast's adherence to "the old and stupid theory of "protection" and recommended that the North instead establish a tariff for revenue as a "remedy" for its growing foreign and domestic ills. ${ }^{38}$

"Whether it is so intended or not," remarked London's Saturday Review, the tariff "must be read as a solemn declaration by the North that it is irretrievably severed from the South." "39 Scotland's widely circulated Dundee Courier thought the Morrill Tariff "a sad disaster ... disastrous to the prosperity of the trans-Atlantic republics." The Morrill Tariff would "be doubly impolitic and fatal" when contrasted with the South's commercial policy; "if the North becomes strongly Protectionist, then it is not improbable that the trade now concentrated in the harbours of the Northern States will remove itself to those of the rival Federation." ${ }^{40}$ While war itself appeared by no means certain, the tariff issue appeared to make even peaceful reunion impossible.

"Protection was quite as much a cause of the disruption of the Union as Slavery," the London Times pronounced on March 12, 1861, ten days after the Morrill Tariff had become law. That day's editorial was more condemnatory of Republican failings and diplomatic insensitivity than it was proSouth in sentiment, and according to Martin Crawford, it "may legitimately be viewed," as the Times's "editorial manifesto on the disunion crisis."11 The Times also remarked upon how "the Tariff bill has much changed the tone of public feeling with reference to the Secessionists, and none here, even those whose sympathies are with the Northern States, attempt to justify the course which the Protectionists in Congress have pursued." That same day, the London Star stated that the Confederacy "will unquestionably make free trade the basis of its commercial policy ... the injury which the Southern States have sustained from the high tariff upheld by the North has had no small share in bringing about their secession." ${ }^{42}$

British newspapers continued to voice discontent with the Morrill Tariff, even as they highlighted growing sectional divisions in the United States. Five days after the bill's passage, England's Bradford Observer portended that the Morrill Tariff "will be a good argument for the Secessionists. . . . A better measure could not be hit upon for consolidating the Southern confederacy and obtaining recognition of its independence by foreign nations." ${ }^{33}$ The London Times noted that the tariff's passage undid "all the progress that has been made in the direction of Free Trade, and in manacling their country once more in the fetters of a Protection amounting

42 JOURNAL OF THE CIVIL WAR ERA, VOLUME 3, ISSUE 1 
to prohibition, effectively changing "the tone of public feeling with reference to the Secessionists, and none here, even those whose sympathies are with the Northern States, attempt to justify the course." Businesses in Manchester, Sheffield, Newcastle, and Wolverhampton waited in "apprehension" and "anticipation that the tariff has become law." ${ }^{44}$ One Liverpool merchant wrote the Times editors that "the policy, the interest, and the inclination of the Southern people are clearly in favour of Free Trade, and the Morrill Bill ... will render a 'reconstruction' or a pacific 'compromise' .. impossible." ${ }^{45}$ London's conservative Morning Post aptly summed up the dilemma: "Slavery, no doubt, is the blight and plague-spot of the South; but the North has its plague-spot in this prohibitive tariff. . . . It were well if North and South would say to each other ... 'Brother, brother, we are both wrong." ${ }^{\prime 6}$ Ever the stubborn siblings, neither would.

A few days later, London's radical Daily Newes acknowledged that "there is probably no event which has attracted so much regretful attention as the adoption by the Northern American Union of the Morrill Tariff." At the same time that France, Russia, Spain, Japan, and China were opening themselves up to "mercantile enterprise," "the Northern protectionists rush in selfishly with a programme framed in their own interest, and certain to widen the breach between the disputing sections of the nation.... It is disgraceful in the present crisis of American affairs for these narrow politicians to be driving in the wedge of disunion with might and main, for the effect of the new fiscal legislation must inevitably be to render a reconciliation between the North and South impossible." 47 "If the United States persevere in their policy of inactivity," the Sheffield छ Rotherham Independent similarly warned, "our government cannot do less than recognize the de facto government of the South." The South's constitution, the paper noted, prohibited protection of "any branch of industry" and reduced duties enough to "form a very substantial compensation to foreigners for the loss sustained by the Morrill tariff bill." ${ }^{\prime 8}$ All the North had offered in return were prohibitive trade restrictions.

Scotland's Glasgow Herald reprinted an editorial from the New York Herald comparing the northern and southern tariff policies, though it was "impossible to deny to the Southern tariff an exemplification of statesmanship, enlightenment, wisdom, and a knowledge of governing a great and enterprising people, which are wholly wanting in the other document." They were as different "in spirit as the eighteenth and the nineteenth centuries." The Morrill Tariff "is the most ignorant, useless, blundering, and pernicious enactment that ever was concocted," while the South's tariff "will command the admiration" of Europe, "guided by that conviction in their policy as regards the two sections. ... France and England will find little 
difficulty now in recognizing the independence of the Confederate States of the South. The statesmen of these nations care nothing for our eternal nigger question. Their own commercial interests abroad are all in all to them." ${ }^{49}$ London's Morning Herald similarly believed the South's tariff to be "simple and intelligible, while the Northern is complicated, self-contradictory, and, in many points, unintelligible . . . it is easy, therefore, to see which set of diplomats ... is the more likely to succeed... . The Southern Confederacy has a mighty destiny before it," while the North was perched upon the brink of "ruin., ${ }^{50}$ The Herald's Boston correspondent reported on the feeling of gloom in the North: "The passage of the new tariff law was a most egregious blunder," especially "in the face of the existence of a free trade confederacy on our very border" and with the European nations bound to look more favorably on the latter. ${ }^{51}$

"The opinion is becoming universal," the Morning Post sardonically reported, that the northerners "have made a monstrous blunder in passing the Morrill tariff law ... and thus forfeited not a little" of the moral high ground..$^{52}$ The conservative pro-North magazine Fraser's called the new northern tariff an "affront and wrong to the adhering Slave States, and raises a wall against the return of the seceders.... It gives them an ex post facto justification.... If such a law could be permanent, its mischief would be enormous." ${ }^{53}$ It appeared to critics on both sides of the Atlantic that the North had to change tactics if it were to undercut possible European recognition of the Confederacy.

The South, hoisting the free trade banner for its foreign observers, appeared to be starting strong at the war's outset in convincing Europe to recognize her independence. "However hollow their reasons for revolution," remarked the Bury and Norwich Post, the southerners "have shown a degree of energy, perseverance, and tact in carrying out their designs, strikingly in contrast with the pusillanimity and vacillating imbecility" of the North. ${ }^{54}$ British conservatives and the Lancaster Gazette speculated in turn that the North was in actuality going to war for protectionism and empire..$^{5}$

On May 4, 1861, the Confederate commissioners to England-Mann, Rost, and Yancey-gained an interview with John Russell, the British foreign secretary, through the efforts of William Gregory, a sympathetic member of the House of Commons. The Morrill Tariff, they stated to Russell, was the primary cause of secession. The South only desired free trade with the world, a sentiment they repeated to Russell in written form on August 14: the Confederacy could clothe "all the nations of Europe under the benign influence of peace and free trade." The commissioners were acting under the direct orders of Robert Toombs, then Confederate secretary of 
state. He also urged them to emphasize that secession had been necessary owing to the "the manufacturing States of the North" historically forcing the South, since 1828, to "pay bounties to northern manufacturers in the shape of high protective duties on foreign imports." This unjust policy, Toombs continued, was "strikingly illustrated by the high protective tariff just adopted by the Government at Washington." Toombs believed this line of argument would show wise Confederate action "in the estimation of those countries whose commercial interests, like those of Great Britain, are diametrically opposed to protective tariffs." He expected Great Britain "will speedily acknowledge our independence" and granted the commissioners the power to negotiate treaties, for the principle aim "in their policy with foreign Governments is peace and commerce." Toombs even quoted Richard Cobden's maxim that the Confederate states would "buy where you can buy cheapest, and sell where you can sell dearest." With Confederate maintenance of a revenue tariff, their policy would "closely approximate free trade" and thereby "render their markets peculiarly accessible to the manufactories of Europe." ${ }^{\prime 6}$ Thus, by March 1861, the Confederate state department had enunciated through official channels its policy of free trade diplomacy toward Europe. ${ }^{57}$

The northern and southern views on the tariff "are fatal to all hopes of reconciliation," remarked the Sheffield छ Rotherham Independent in midMay, as were the dueling antagonisms of slave and free labor. ${ }^{58}$ Confederate diplomat Edwin de Leon wrote a letter to the editors of the London Times on May 25 that slavery was "a mere pretext" for secession, as shown by continued northern defense of the institution through its guarantee of slavery where it existed and through its enforcement of the fugitive slave law. ${ }^{59} \mathrm{By}$ the end of May, the pro-free trade Preston Guardian even asserted that when northerners cried "no slavery," they "meant protection."60

Some Englishmen expressed their doubts as to northern antislavery sincerity and sought recognition for the South, not "from any advocacy of slavery, but from love of peace and unrestricted commerce, from horror of civil war and future years of deadly hatred." ${ }^{11}$ William H. Gregory, a member of the House of Commons, unsuccessfully led the charge for British recognition, arguing that it would bring an end to the slave trade, keep the states from fighting a "fratricidal, needless war," and act as retaliation against the North's Morrill tariff. Secession "nullifies that selfish, shortsighted, retrograde policy, and the Western States ought to be thankful."62 Northern minister to England, Charles Francis Adams Sr., after meeting with Britain's foreign secretary, John Russell, similarly noted that the Morrill Tariff and the conflict's seeming nonissue of slavery still left southern recognition as a viable option. ${ }^{63}$ Seward in turn instructed Adams to 
respond to southern free trade diplomacy with counterarguments that the Confederacy could not maintain a policy of free trade during times of war and that a war against the Union was much more detrimental to British commerce than a protective tariff. ${ }^{4}$

To many northerners, Britain's maintenance of neutrality in turn increasingly appeared to benefit the South and undermine the Union. Some Americans and Englishmen correspondingly began to see the existing tariff as punishment for Britain's seemingly ambivalent stance. One northerner, for example, suggested that continuance of the Morrill Tariff was chastisement for British neutrality, which northerners viewed as an act of hostility. "Had the English Government treated the Secessionists as they deserve to be treated," he wrote in the Morning Post, "there would have been prompt sentence of death passed upon the new tariff, and it would have been but a serpent strangled in its cradle." ${ }^{65}$ The Morning Post then incorrectly asserted that relaxations to the Morrill Tariff had even been tantalizingly held out by the Union's treasury secretary, Salmon Chase, in the hope that it would "induce the British Government to depart from that position of neutrality." ${ }^{6}$ William Rathbone Greg, in the National Review, made "perfectly clear" that England was "unable to sympathise heartily with either rival," as the North was overly ambitious, insolent, and England was "aggrieved by her tariffs," while the South was "friendly and free trading" but also "fanatically sLAVE, and Slavery is the object of our rooted detestation." ${ }^{67}$

The protectionist-free trade argument remained prevalent in Britain from 1861 well into 1862. Liverpool's avidly pro-South merchant and London Times writer James Spence, in his influential publication The American Union (1861), for instance, spent but one chapter on slavery and the other seven on the Morrill Tariff, the right to secession, and why he thought a future reunion was culturally and philosophically impossible. ${ }^{68}$ After a close reading of Spence in late 1861, Charles Dickens himself became decidedly pro-South and argued in the pages of All the Year Round that the Morrill Tariff had "severed the last threads which bound the North and South together." ${ }^{69}$ Scotland's Dundee Courier went so far as to assert that if the Morrill Tariff "were annulled ... it would act like magic upon the trade of this country, and tend to terminate the civil war."70

John Bright wrote Charles Sumner that the subject of the tariff was "of great importance," that there was little "that would more restore sympathy between England and the States than the repeal of the present monstrous and absurd Tariff. It gives all the speakers and writers for the South an extraordinary advantage in this country in their discussion of the American question." ${ }^{\text {11 }}$ Further demonstrating the tariff's transatlantic

46 JOURNAL OF THE CIVIL WAR ERA, VOLUME 3, ISSUE 1 

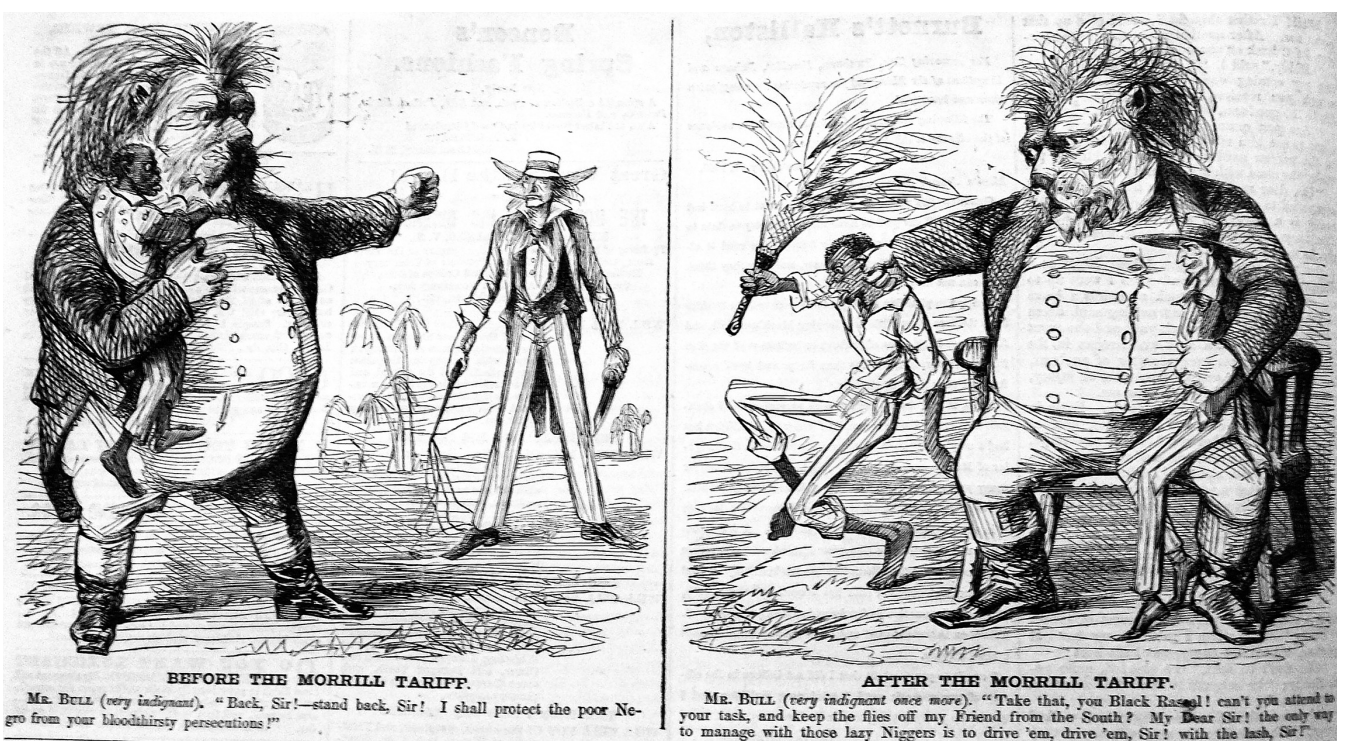

Figure 1

"Before and After the Morrill Tariff." Harper's, a pro-Union magazine, portrays the North's anger over Britain's apparent shift from moral outrage to support for Southern slavery owing to the Morrill Tariff's passage. "Before the Morrill Tariff: Mr. Bull (very indignant), 'Back, Sir!-stand back, Sir! I shall protect the poor Negro from your bloodthirsty persecutions!" "After the Morrill Tariff: Mr. Bull (very indignant once more), 'Take that, you Black Rascal! can't you attend to your task, and keep the flies off my Friend from the South? My Dear Sir! the only way to manage with those lazy Niggers is to drive 'em, drive 'em, Sir! with the lash, Sir!'” (Harper's Weekly, April 2O, 1861, 256).

traction, following the southern rout of northern troops at Bull Run in July 1861, New York banker August Belmont, attempting to obtain a Union loan from the British, reminded Prime Minister Palmerston of the South's continued maintenance of slavery. Palmerston retorted: "We do not like slavery, but we want cotton and we dislike very much your Morrill tariff.", 2

To add moral outrage to economic injury, in November English blankets and clothing had been sent "to save the troops from perishing by the thousands in the coming winter" but were excluded from American shores owing to the Morrill Tariff's prohibitive provisions. The Leeds Mercury denounced the North's "protectionist mania, which in the first place has contributed largely to drive off the Southern States from the Union, and then actually interfered to prevent the clothing of the Northern armies at the most critical period of the war." ${ }^{73}$ 
Such continued British support for the Confederacy's free trade diplomacy is all the more remarkable considering that the North controlled much of the outgoing information to Europe regarding the war and, until the end of 1861, the Confederacy's official European propagandistic and diplomatic activities had been negligible. Whatever favorable coverage they had received thus far was owed predominantly to Britain's nongovernmental southern sympathizers. Nevertheless, northern control of transatlantic information flows was beginning to take its toll on Confederate sympathies in Europe. Such an imbalance concerning the coverage of the war inspired, first, Confederate secretary of state R. M. T. Hunter and, afterward, Hunter's 1862 replacement, Judah P. Benjamin, to send Henry Hotze to England to ghostwrite editorials in leading London newspapers, emphasizing northern tyranny, scientific racialism, and the benefits offered to Great Britain by the Confederacy's free trade policies. Hotze was shocked to find a near lack of any professional Confederate propaganda machine within the British press.

Hotze's own first successes did not come about until February 1862, with the Morning Post editorial page opening itself as a promising outlet for encouraging British recognition of the Confederacy. Hotze asked the paper's readers if Britain could allow southern cotton and tobacco fields to be walled in by the Morrill Tariff, "imposed by fire and sword." A united America and a dependent South, he warned, would offer an insular empire similar to that of the Chinese: "what should the North care for foreign commerce? When it can buy in a close market all it needs, and sell in a close market all it produces, what need is there for reciprocal treaties with foreign nations?" In subsequent weeks, he also began contributing to the London Times, the Standard, the Herald, and the Money Market Review. With the first issue appearing in print on May 1, Hotze next created his own paper, the Index, to better disseminate Confederate propaganda in Britain and France, and its printing continued until August 1865. ${ }^{74}$

Northern seizure of the Confederacy's special commissioners bound for Europe upon the Trent in late 1861 further agitated already tense UnionBritish relations. Amid the affair and throughout 1861, Britain's minister in Washington, Lord Lyons, had continued to express to Lord John Russell his hope that the Morrill Tariff might be replaced by a revenue tariff. ${ }^{75}$ Furthermore, Confederate secretary of state Hunter's order to James Mason, the recently released commissioner to Britain, was that he continue to London and express, among other sentiments regarding self-government and the right to defend itself, the South's low import duties and its "great interest" in producing and exporting staples, thereby binding "them 
to the policy of free trade." Playing on Britain's free trade heartstrings, he was also to stress that the Confederacy's "empire ... of free trade" was essential to the progress of humankind and "to preserve peace."76

John Slidell, Confederate special commissioner to France, similarly reported such sentiments to the French minister in February 1862.77 Thurlow Weed, the Union's unofficial emissary to France, reported to Secretary of State William Seward that the French emperor was hinting at breaking the Union blockade or recognizing the Confederacy owing to the detrimental economic problems striking France, continued northern military failures, and the unpopularity of the Morrill Tariff. ${ }^{78}$ A couple weeks after Weed's message, William S. Lindsay, a radical member of Parliament and wealthy British shipowner hurt by the northern tariff and the blockade, traveled to Paris to urge Napoleon III to spur English action on the matter. On April 11, Lindsay emphasized Confederate propagandistic talking points to the French emperor: particularly that the North went to war not for emancipation but for the Morrill Tariff and southern subjugation. ${ }^{79}$

In emphasizing that the Civil War was at heart over the issue of slavery, John Bright noted in December 1861 that "there is another cause which is sometimes in England assigned for this great misfortune, which is, the protective theories in operation in the Union, and the maintenance of a high tariff ... no American ... attributed the disasters of the Union to that cause. It is an argument made use of by ignorant Englishmen, but never by informed Americans." Nor had the tariff question arisen, he noted, during the attempts at compromise in December of the year before. "It is a question of slavery" and nothing else. ${ }^{80}$

When Benjamin took over the Confederate state department in the spring of 1862, he wrote to Mason that, owing to the North's "system of deception," it was "not wise to neglect" European public opinion. Benjamin supplied Mason, Hotze, and the Confederate minister to France, John Slidell, with the services of Edwin de Leon along with $\$ 25,000$ to be used to enlighten public opinion "through the press" in Great Britain and France. ${ }^{81}$ Mason thereafter put de Leon in touch with his Parisian connections as well as James Spence, one of Britain's more effective southern propagandists. $^{82}$

In Parliament, southern sympathizers like William Lindsay and William Gregory called for recognition of the ostensibly pro-free trade Confederacy in order to end the war. Lindsay called for peaceful separation and claimed that the war had been caused by longstanding, unjust, and injurious northern protectionist taxation upon the South, culminating in the Morrill Tariff. Gregory called for recognition and declared that "by the 
new tariff the rulers of the United States have virtually proclaimed that the great American Continent is to be closed to the products of Europe. By the Morrill tariff they resolved on scourging us with whips." When a pro-Union member eloquently responded as to why he believed "that slavery was the real cause of the issue," he was forced to speak over shouts of "No, no!" and "The tariff!" 83

Such Confederate editorial and parliamentary efforts apparently paid off with propagandistic dividends, as recognized by Charles Sumner and the Union minister to France, John Bigelow. In mid-October 1862, Sumner, who had tried to discourage offending England through high tariffs, expressed his own frustration at the general lack of northern support in England to John Bright: "We are fighting the battle of civilization, and their [English] public men and newspapers should recognize and declare the true character of the conflict. . . . And yet this wicked rebellion has found backing in England." ${ }^{84}$ Richard Cobden and John Bright, it should be reiterated, were among the loudest English voices in defending the North's position. Bright in particular continued to give speeches denouncing the tariff argument, and they had wide reception. For instance, having just read Bright's recent speech in Rochdale, Cassius M. Clay, the Union's Russian ambassador, complimented Bright for showing "so forcibly" that "the tariff had nothing to do with our revolt." ${ }^{85}$ Bright's radical and polarizing pro-Union arguments did have some influence in turning British opinion, although his popularity was waning considerably during this time. ${ }^{86}$

But it was John Stuart Mill who began offering the best refutation of the protection-free trade thesis in the British press. By the beginning of 1862, the tariff issue had gained enough public traction to earn Mill's intellectual ire, and he proved quite effective at voicing his opinion concerning slavery's centrality to the conflict. He sought to refute "a theory in England, believed by some, half believed by many more ... that, on the side of the North, the question is not one of slavery at all." Assuming this to be true, he asked, then "what are the Southern chiefs fighting about? Their apologists in England say that it is about tariffs, and similar trumpery." Yet the southerners "say nothing of the kind. They tell the world ... that the object of the fight was slavery." Mill noted that the Nullification Crisis of 1832which had not ended in secession-stemmed from a tariff so high that the Morrill tariff would look like "a free-trade tariff" in comparison. "Slavery alone was thought of, alone talked of . . the South separated on slavery, and proclaimed slavery as the one cause of separation." He also predicted that the Civil War would soon placate the abolitionists on both sides of the Atlantic: particularly that, as the war progressed, "the contest would become distinctly an anti-slavery one." ${ }^{\circ 7}$ Mill's argument was echoed in 
J. E. Cairnes's publication The Slave Power (1862). Cairnes was especially "at some pains to show that the question at issue between North and South is not one of tariffs," a view that had "pertinaciously" been "put forward by writers in the interest of the South." ${ }^{8}$

Ironically, Gladstone and Russell initially used Mill and Cairnes's argument to strengthen their support for southern independence. ${ }^{89}$ London's increasingly pro-North Daily Neres, however, followed Mill's counterattack with an anti-tariff argument of its own, observing that, as to the question of why the South seceded, "the partisans of secession here, being crafty in their generation, are ready with an answer calculated to find its way to the English heart. They at once reply, 'A protectionist policy, a hostile tariff." The Daily News pointed out, however, that the Morrill Tariff had nothing to do with secession. After all, the Democrats had held a majority in the Senate at the time of the tariff's movement through the Republicancontrolled House; they could easily have stopped the tariff's passage in its tracks. "The eternal nigger' stands in bold relief in the front of this horrible offending. There is no hustling him out of the way, he crops up everywhere. Tariffs only hide him for a moment." 90

While the slavery cause was thus steadily gaining ground on the South's free trade argument, some British papers nevertheless continued to attribute the Civil War's cause "not to slavery, but to the Morrill tariff." ${ }^{11}$ In late May 1862, Scotland's Glasgow Herald printed a letter stating that secession had come about to free the South from its northern dependence and to have "free trade with all the world." ${ }^{2}$ In response, a pro-North respondent asked some insightful questions: "If the Southern Democrats cherished free trade so greatly, he asked, then why had they not given their support to the free trade northern Democratic presidential candidate Stephen Douglas? Why did the senators resign when they had the votes to block the Morrill Tariff bill, and why did the secessionist leader from Georgia Robert Toombs vote for it? Because they had wanted the tariff to pass, the northern proponent concluded. ${ }^{93}$

In part hoping to garner moral support from those in Britain who yet thought there was little difference between the governments of the North and South regarding slavery, Lincoln made his Emancipation Proclamation on September 22, 1862. The proclamation's expected transatlantic gunshot initially misfired; as John Bright observed to Charles Sumner shortly after it was made, the proclamation was initially "misrepresented" in England. ${ }^{94}$ As Howard Jones has pointed out, "these events of autumn 1862 actually heightened British interest in intervention." Pro-South sentiment among the British press stemming from its free trade diplomacy certainly did not lessen such interventionist interest. At this time, Britain came closer than 
ever to conceding to European mediation. Even Richard Cobden, staunch opponent of southern slavery and a northern supporter, had himself at first feared the use of emancipation as a weapon. ${ }^{95}$

The Emancipation Proclamation thus initially increased the potential for British recognition of the Confederacy, although it would soon help in turning the transatlantic debate from tariffs and blockades to slavery. By 1863, the tariff argument had, correspondingly, lost editorial and public support, and Mill's prophecy began to bear fruit, owing to numerous nongovernmental northern propagandistic efforts in England, the Union victory at Antietam in September 1862, and a growing acceptance of the sincerity of Lincoln's proclamation. ${ }^{96}$

Previously in support of peaceful separation and free trade, the liberal Bradford Observer and Leeds Mercury, for instance, ultimately came down on the Union side following the proclamation. ${ }^{97}$ Richard Cobdenalthough he condemned the northern blockade and, as Charles Francis Adams Jr. described, although the northern tariff "was odious in his eyes, a violation equally of economic principles and of international comity"also ultimately gave his wholehearted endorsement to the northern cause by December 1862. Cobden wrote Sumner in February 1863 that the Emancipation Proclamation had aroused "our old anti-slavery feeling ... and it has been gathering strength ever since." It also led to meetings, the result of which "closed the mouths of those who have been advocating the side of the South." John Bright seconded Cobden's observation, writing his American friend Cyrus Field that "opinion here has changed greatly. In almost every town great meetings are being held to pass resolutions in favor of the North, and the advocates of the South are pretty much put down."98

As early as February 1862, Republican proponents had already crossed the Atlantic to meet in London to "aid in removing the misapprehensions which prevailed," especially concerning the causes of the Civil War. "It was simply slavery, and nothing else," these northern agents had argued. "Neither the Morrill Tariff, nor any other causes, had the weight of a feather in the matter, except this question of slavery, and the power of extending it to the (as yet) unoccupied territories of the Union." 99 A growing British belief in the North's antislavery goals in the months following Lincoln's September proclamation began to make such anti-tariff propagandistic efforts more effective.

Pro-South advocates had created the Manchester Southern Club and Southern Independence Associations in Lancashire and London to combat this mounting abolitionist argument, offering countering promises that the Confederacy would never reopen the slave trade and would ultimately 
emancipate its slaves. In Parliament, John Roebuck made failed attempts to recognize the South, suggesting that the North was hypocritical on the slavery issue and "the South offers to us perfect free trade."100

Yet these Confederate arguments were overwhelmed by northern antislavery propaganda. African American and other pro-North advocates in turn gained greater success in their attempts to persuade the British working class to favor the Union by $1863 .{ }^{101}$ American abolitionists like Henry Ward Beecher, for instance, toured England calling for northern support. In October 1863, Beecher told a Liverpool audience, which was "foaming" with "madness," that the Morrill Tariff had in fact only been passed "to pay off the previous Democratic [Buchanan] administration's debt. . . . It was the South that obliged the North to put the tariff on." Beecher even promised that "there is nothing more certain in the future than that America is bound to join with Great Britain in the worldwide doctrine of free trade." ${ }^{102}$ Similarly, in March 1864, pro-North Englishman Ernest Jones gave a popular speech in Rochdale, noting, "some gentlemen here tell you that the rebellion is for free trade-that it was a revolt against the Morrill tariff." Yet it was notable, for example, that the Crittenden compromise, proffered unsuccessfully in December 1860, had contained "not one word about free trade or the Morrill tariff. . . . It is slavery in the beginning, slavery to the end."103 Under the growing onslaught of the moral-slavery arguments, and even with Beecher's tantalizing promises of future free trade with the Union, the South's own free trade argument correspondingly lost ground.

Noting this trend, the Leeds Mercury recalled in January of 1864 "that during the first year of the war slavery was entirely ignored as a cause.... At that time the public, or at least that portion which could make itself heard, resolutely refused to hear a word about slavery, and the 'Morrill Tariff' was held to be the key to the whole affair." It was clear by now "that slavery is the chief stone of the corner in the Southern Confederacy. . . . It is only the English Confederates" such as the Southern Independence Association "who attempt to hide the truth." Furthermore, "when the British public, seeking enlightenment, casts its eyes northwards, it sees the development of a policy which shows that slavery has a great deal to do with the object of the war, whatever it had to do with the cause of the war. Nominally the war is a war against rebellion: practically it is a war against slavery." ${ }^{104}$ Similar arguments appeared throughout British publications. ${ }^{105}$

Similarly, in 1865, Goldwin Smith, hoping to stem the tide of anti-British sentiment in the United States, attempted to explain British acceptance of the tariff argument to a Boston audience: 
Had you been able to say plainly at the outset that you were fighting against Slavery. ... It would scarcely have been brought to believe that this great contest was only about a Tariff. ... I have heard the Tariff Theory called the most successful lie in history. Very successful it certainly was, and its influence in misleading England ought not to be overlooked. It was propounded with great skill, and it came out just at the right time, before people had formed their opinions, and when they were glad to have a theory presented to their minds. But its success would have been short-lived, had it not received what seemed authoritative confirmation from the language of statesmen here. ${ }^{106}$

In conclusion, through an examination of American, Irish, Scottish, and English sources, the tariff takes on a transatlantic significance that has been overlooked in previous scholarship. Along with various other transatlantic crises in the first years of the conflict, the Morrill Tariff heightened anti-northern sentiment as well as the prospects for European recognition, particularly within the British press. British belief that slavery was the central cause of the conflict did not come to dominate until well into the war. It was a few months after Lincoln announced his September 1862 Emancipation Proclamation before the North and its transnational antislavery allies effectively began to counteract the tariff argument, as well as a host of other issues that adversely affected Union-British relations. Amid a broad array of issues that had led to pro-southern or at least antiUnion sentiment, they responded with their own moralistic propaganda, especially as the war openly turned more and more into a conflict over slavery. Whether or not secessionists foresaw the possible diplomatic benefits the tariff might bring in Europe, the Morrill Tariff was thereafter used effectively by the British press, the Confederate state department, and Confederate sympathizers throughout free-trading Great Britain during the first years of the war.

Although the Morrill Tariff and other Anglo-American fallouts ultimately failed to gain British recognition of the Confederacy, the British press had been quick to take up the South's free trade propaganda, a stance that at the time seemed to enhance the prospect of recognition. By the beginning of 1862, the Confederacy began more directly to propagate its free trade diplomacy in the British press through agents like Hotze and de Leon, and both Union and Confederate supporters recognized the influence of the tariff argument upon British public opinion. It was not until 1863 that the Union's advocates had successfully shifted the focus of debate from tariffs, blockades, and King Cotton to that of slavery. The Confederacy's free trade diplomacy thus aided in creating transatlantic 
confusion concerning the Civil War's causation and in gaining British support. Alongside the diplomacy of King Cotton, therefore, historians need to remember as well the South's diplomacy of free trade.

NOTES

I am especially grateful to Duncan Campbell, George Forgie, Rachel Herrmann, Phil Magness, the journal's anonymous readers, and the attendees at the 2010 Porter L. Fortune Jr. Symposium for their helpful comments and suggestions.

1. Frank W. Taussig, The Tariff History of the United States (New York: G. P. Putnam's Sons, 1931), 158-60. For more detailed studies of Justin Morrill and the Morrill Tariff, see Phillip W. Magness, "Morrill and the Missing Industries: Strategic Lobbying Behavior and the Tariff, 1858-1861," Journal of the Early Republic 29 (Summer 2009): 287-329; Jane Flaherty, "Incidental Protection: An Examination of the Morrill Tariff," Essays in Economic and Business History 19 (2001): 103-18; and William Belmont Parker, The Life and Public Services of Justin Smith Morrill (Boston: Houghton Mifflin, 1924). For a detailed account of Civil War-era Republican economic policies, see Heather Cox Richardson, The Greatest Nation on Earth: Republican Economic Policies during the Civil War (Cambridge, Mass.: Harvard University Press, 1997).

2. Richard Cobden to Charles Sumner, December 5, 1861, reel 23, Charles Sumner Papers, Library of Congress, Washington, D.C.

3. See, for instance, Anthony Howe, Free Trade and Liberal England, 1846-1946 (Oxford: Oxford University Press, 1997); and Frank Trentmann, Free Trade Nation: Commerce, Consumption, and Civil Society in Modern Britain (Oxford: Oxford University Press, 2008).

4. Taussig, Tariff History of the United States, 158-59; Magness, "Morrill and the Missing Industries," 327-28; Flaherty, "Incidental Protection”; Duncan A. Campbell, English Public Opinion and the American Civil War (New York: Boydell and Brewer, 2003), 41.

5. William G. Carleton, "Tariffs and the Rise of Sectionalism," Current History 42 (June 1962): 333-38; Richard H. Luthin, "Abraham Lincoln and the Tariff," American Historical Review 49 (July 1944): 614; John Majewski, Modernizing a Slave Economy: The Economic Vision of the Confederate Nation (Chapel Hill: University of North Carolina Press, 2009), 108-39.

6. Douglas A. Lorimer, "The Role of Anti-Slavery Sentiment in English Reactions to the American Civil War," Historical Journal 19 (June 1976): 405-20.

7. Phillip E. Myers, Caution and Cooperation: The American Civil War in BritishAmerican Relations (Kent, Ohio: Kent State University Press, 2008); Jay Sexton, Debtor Diplomacy: Finance and American Foreign Relations in the Civil War Era, 1837-1873 (Oxford: Oxford University Press, 2005).

8. Martin Crawford, The Anglo-American Crisis of the Mid-Nineteenth Century: The Times and America, 1850-1862 (Athens: University of Georgia Press, 1987), 93.

9. Campbell, English Public Opinion, 41-48. 
10. See, among many others, Donaldson Jordan and Edwin J. Pratt, Europe and the American Civil War (Boston: Houghton Mifflin, 1931); Richard J. M. Blackett, Divided Hearts: Britain and the American Civil War (Baton Rouge: Louisiana State University Press, 2001); Frank J. Merli, The Alabama, British Neutrality, and the American Civil War (Bloomington: Indiana University Press, 2004); David F. Krein, The Last Palmerston Government: Foreign Policy, Domestic Politics, and the Genesis of "Splendid Isolation"(Ames: Iowa State University Press, 1978); and Joseph M. Hernon Jr., "British Sympathies in the American Civil War: A Reconsideration," Journal of Southern History 33 (August 1967): 356-67.

11. Brian Jenkins, Britain and the War for the Union, 2 vols. (Montreal: McGillQueen's Press, 1974), 1:81; Howard Jones, Blue and Gray Diplomacy: A History of Union and Confederate Foreign Relations (Chapel Hill: University of North Carolina Press, 2010), 18; David P. Crook, The North, the South, and the Powers, 1861-1865 (New York: Wiley, 1974), 21-22.

12. Thomas J. Keiser, "The English Press and the American Civil War" (PhD diss., University of Reading, 1971), 101; Campbell, English Public Opinion, 44-45.

13. D. G. Wright and D. E. Wright, for instance, discuss the difficulties surrounding English opinion by using the towns of Bradford and Leeds as case studies in "English Opinion on Secession: A Note," Journal of American Studies 5 (August 1971): 151-54.

14. Charles A. Beard and Mary Beard, The Rise of American Civilization, 2 vols. (New York: Macmillan, 1927), 2:35-38; Richard Hofstadter, "The Tariff Issue on the Eve of the Civil War," American Historical Review 44 (October 1938): 50-55; Alan Nevins, The Emergence of Lincoln, vol. 2, Prologue to Civil War (New York: Scribner, 1950), 465; Hugh Tulloch, The Debate on the American Civil War Era (Manchester: Manchester University Press, 1999), 121-22; Marc Egnal, "The Beards Were Right: Parties in the North, 1840-1860," Civil War History 47 (2001): 30-56; Egnal, Clash of Extremes: The Economic Origins of the Civil War (New York: Hill and Wang, 2009), 7-8; Jane Flaherty, “The Exhausted Condition of the Treasury' on the Eve of the Civil War," Civil War History 55 (June 2009): 248-52; Mark Thornton and Robert B. Ekelund, Tariffs, Blockades, and Inflation: The Economics of the Civil War (Wilmington, Del.: SR Books, 2004), 2, 22-26; and Magness, "Morrill and the Missing Industries," 287.

15. William W. Freehling, Prelude to Civil War: The Nullification Controversy in South Carolina, 1816-1836 (New York: Harper \& Row, 1966), 255.

16. For this lack of cohesion over the tariff, see Robert Royal Russel, Economic Aspects of Southern Sectionalism, 1840-1861 (Urbana: University of Illinois Press, 1924); Brian Schoen, The Fragile Fabric of Union: Cotton, Federal Politics, and the Global Origins of the Civil War (Baltimore: Johns Hopkins University Press, 2009); Majewski, Modernizing a Slave Economy; and Jay Carlander and John Majewski, "Imagining 'A Great Manufacturing Empire': Virginia and the Possibilities of a Confederate Tariff," Civil War History 49 (December 2003): 334-52.

17. Philip S. Foner, British Labor and the American Civil War (New York: Holmes \& Meier, 1981), 3-4; Campbell, English Public Opinion, 41; Mary Ellison, Support for 
Secession: Lancashire and the American Civil War (Chicago: University of Chicago Press, 1972).

18. Henry Harrison Simms, Life of Robert M. T. Hunter: A Study in Sectionalism and Secession (Richmond: William Byrd Press, 1935), 108-9.

19. Osborn H. Oldroyd, The Lincoln Memorial (New York: G. W. Carleton and Co., 1882), 76; William H. Herndon and Jesse W. Weik, Herndon's Lincoln, 3 vols. (Chicago: Norman D. Sampson, 1889), 1:102; Luthin, "Lincoln and the Tariff"; Speech of February 15, 1861, The Collected Works of Abraham Lincoln, ed. Roy P. Basler, 9 vols. (New Brunswick, N.J.: Rutgers University Press, 1953), 4:213.

20. Hofstadter, “Tariff Issue”; Richardson, Greatest Nation on Earth, 111.

21. London Times, March 26, 1861.

22. Crawford, Anglo-American Crisis, 93.

23. Edwin de Leon, Secret History of Confederate Diplomacy Abroad, ed. William C. Davis (Lawrence: University Press of Kansas, 2005), 145-46; Lorimer, "Role of AntiSlavery Sentiment," 405; Peter d'A. Jones, "The History of a Myth: British Workers and the American Civil War," epilogue to Ellison, Support for Secession, 199-219; Royden Harrison, "British Labour and the Confederacy: A Note on the Southern Sympathies of Some British Working Class Journals and Leaders during the American Civil War," International Review of Social History 2 (April 1957): 78-105; Duncan Andrew Campbell, Unlikely Allies: Britain, American and the Victorian Origins of the Special Relationship (London: Hambledon Continuum, 2007), 165, 167-69.

24. Bigelow to Hargreaves, September 14, 1861, John Bigelow Papers, New York Public Library; Charles Francis Adams Jr., "The Richard Cobden Centennial. Speech of Charles Francis Adams at the Dinner of the Free Trade League at the Hotel Vendome, Boston, on the Evening of June 2, 1904," 2, held at the Massachusetts Historical Society, Boston, Mass.

25. New York Times, March 23, 1861.

26. Congressional Globe, 36th Cong., 2nd sess., appendix, 1153, 1190.

27. Quoted in S. D. Carpenter, Logic of History: Five Hundred Political Texts: Being Concentrated Extracts of Abolitionism (Madison, Wisc.: S. D. Carpenter, 1864), 147.

28. New York Times, February 14, 1861. See also New York Times, March 26, 1861.

29. Quoted in Campbell, English Public Opinion, 44.

30. Morning Chronicle, February 12, 1861.

31. Morning Chronicle, February 26, 1861.

32. (Edinburgh) Caledonian Mercury, February 28, 1861.

33. Sheffield $\Xi$ Rotherham Independent, March 9, 1861.

34. John William Draper, History of the American Civil War, 3 vols. (New York: Harper \& Brothers, 1868), 2:510.

35. London Times, March 8, 1861, reprinted in New York Times, March 26, 1861; Crawford, Anglo-American Crisis, 95.

36. Once a Week, March 16, 1861.

37. Stephen Meardon, "Richard Cobden's American Quandary: Negotiating Peace, Free Trade, and Anti-Slavery," in Rethinking Nineteenth-Century Liberalism, ed. 
Anthony Howe and Simon Morgan (Aldershot, England: Ashgate, 2006), 213-16; Cobden to Sumner, December 5, 1861, reel 23, Sumner Papers.

38. Cobden to Sumner, December 5, 1861, reel 23; December 12, 19, 1861, January 23, 1862, reel 24, both in Sumner Papers.

39. “The American Tariff Bill," March 9, 1861, Saturday Review of Politics, Literature, Science, and Art (London: John W. Parker and Son, 1861), 11:245.

40. Dundee Courier, March 15, 1861.

41. Crawford, Anglo-American Crisis, 95-96.

42. London Times, March 12, 1861; London Star, March 12, 1861, reprinted in New York Times, March 29, 1869.

43. Bradford Observer, March 7, 1861.

44. London Times, March 12, 1861.

45. London Times, March 13, 1861.

46. (London) Morning Post, March 13, 1861.

47. (London) Daily Neres, March 18, 1861.

48. Sheffield छ Rotherham Independent, March 30, 1861.

49. Glasgow Herald, April 6, 1861.

50. Morning Chronicle, April 6, 1861.

51. Morning Post, April 9, 1861. See also Caledonian Mercury, April 13, 1861.

52. Morning Post, April 17, 1861.

53. Fraser's Magazine, April 1861, 411.

54. Bury and Norwich Post, and Suffolk Herald, April 23, 1861.

55. Donald Bellows, "A Study of British Conservative Reaction to the American Civil War," Journal of Southern History 51 (November 1985): 525; Ellison, Support for Secession, 53.

56. James Morton Callahan, The Diplomatic History of the Southern Confederacy (Baltimore: Johns Hopkins University Press, 1901), 111; Toombs to William L. Yancey, Pierre A. Rost, and A. Dudley Mann, March 16, 1861, and Yancey, Rost, and Mann to Russell, August 14, 1861, both reprinted in A Compilation of the Messages and Papers of the Confederacy Including the Diplomatic Correspondence 1861-1865, ed. James D. Richardson, 2 vols. (Nashville: U.S. Publishing Company, 1905), 2: 4-5, 7, 67.

57. See Toombs to Charles J. Helm, July 22, 1861, and Robert Hunter to Yancey, Rost, and Mann, August 24, 1861, both in Richardson, Compilation of Messages, 46-48, 76.

58. Sheffield छ Rotherham Independent, supplement, May 18, 1861.

59. London Times, May 25, 1861.

60. Preston Guardian, May 29, 1861.

61. Letter reprinted in the Belfast Neres-Letter, June 14, 1861.

62. London Times, June 12, 1861; New York Times, June 24, 1861.

63. Howard Jones, Union in Peril: The Crisis over British Intervention in the Civil

War (Chapel Hill: University of North Carolina Press, 1993), 34.

64. Callahan, Diplomatic History of the Southern Confederacy, 116.

65. Morning Post, June 11, 1861. See also (London) Standard, June 29, 1861.

66. Morning Post, July 13, 1861. Chase had in fact called for an increase to the tariff on July 4, owing to the growing costs of the war. See Frederick J. Blue, Salmon P. Chase:

58 JOURNAL OF THE CIVIL WAR ERA, VOLUME 3, ISSUE 1 
A Life in Politics (Kent, Ohio: Kent State University Press, 1987), 144. The Morning Post might have been referring to northern agent August Belmont's unsuccessful request in the spring of 1861 that Chase get rid of the Morrill Tariff, as he considered "the repeal of the Morrill Tariff worth more to our Cause than the most brilliant victory which arms could achieve over the rebels." Sven Beckert, The Monied Metropolis: New York City and the Consolidation of the American Bourgeoisie, 1850-1896 (Cambridge: Cambridge University Press, 2001), 17.

67. "The Civil War in America," National Review 13 (July 1861): 162.

68. James Spence, The American Union: Its Effect on National Character and Policy, with an Inquiry into Secession as a Constitutional Right, and the Causes of the Disruption (London: R. Hardwicke, 1862); de Leon, Secret History of Confederate Diplomacy Abroad, 149.

69. "The Morrill Tariff," All the Year Round, December 28, 1861; John O. Waller, "Charles Dickens and the American Civil War," Studies in Philology 57 (July 1960): 535-48.

70. Dundee Courier and Daily Argus, July 3, 1861.

71. Bright to Sumner, November 29, 1861, reel 23, Sumner Papers.

72. Belmont to Seward, July 30, 1861, reel 64, William H. Seward Papers, Library of Congress, Washington, D.C.; Jones, Blue and Gray Diplomacy, 62; Sexton, Debtor Diplomacy, 92; Campbell, English Public Opinion, 41-43. Belmont was himself a free trader and sought the Morrill Tariff's repeal as it alienated otherwise sympathetic British liberals. See Irving Katz, August Belmont: A Political Biography (New York: Columbia University Press, 1968), 101-3.

73. Leeds Mercury, November 6, 1861.

74. Henry Hotze, Henry Hotze, Confederate Propagandist: Selected Writings on Revolution, Recognition, and Race, ed. Lonnie A. Burnett (Tuscaloosa: University of Alabama Press, 2008), 15-21; Charles C. Cullop, Confederate Propaganda in Europe 1861-1865 (Coral Gables, Fla.: University of Miami Press, 1969), 28-29, 32-35, 36, 40, 63-64; Morning Post, March 24, 1862, reprinted in Burnett, Hotze, 127.

75. Lyons to Russell, July 8, 1861, reprinted in The American Civil War through British Eyes: Dispatches from British Diplomats, vol. 1, November 1860-April 1862, ed. James J. Barnes and Patience P. Barnes (Kent, Ohio: Kent State University Press, 2003), 138-41; Lyons to Russell, November 22, 1861, reprinted in Private and Confidential: Letters from British Ministers in Washington to the Foreign Secretaries in London, 1844-67, ed. James J. Barnes and Patience P. Barnes (London: Associated University Presses, 1993), 267-68. See also Gordon H. Warren, Fountain of Discontent: The Trent Affair and Freedom of the Seas (Boston: Northeastern University Press, 1981).

76. Hunter to Mason, November 22, 1861, reprinted in Richardson, Compilation of the Messages of the Confederacy, 2:89-90.

77. "Inclosure," Slidell to Benjamin, July 21, 1862, reprinted in Richardson, Compilation of the Messages of the Confederacy, 2:279, 282.

78. Weed to Seward, Paris, January 20, 1862, reel 68, Seward Papers; Lynn M. Case and Warren F. Spencer, The United States and France: Civil War Diplomacy (Philadelphia: University of Pennsylvania Press, 1970), 252. 
79. "Memorandum of Mr. Lindsay's interview with the Emperor," reprinted in Richardson, Compilation of the Messages of the Confederacy, 2:237-38; Charles M. Hubbard, The Burden of Confederate Diplomacy (Knoxville: University of Tennessee Press, 1998), 80-85.

80. John Bright, Speeches on Questions of Public Policy, 2 vols. (London: Macmillan and Co., 1868), 1:174-76.

81. Benjamin to Mason, April 12, 1862, The Public Life and Diplomatic Correspondence of James Mason New York: Neale Publishing Group, 1906), 292-93.

82. Dispatch 14, July 31, 1862; Benjamin to Mason, October 28, 1862; Mason to Benjamin, December 10, 1862; Benjamin to Mason, January 15, 1863, Public Life of Mason, 314, 338-39, 355-56, 350-51.

83. Parliamentary Debates, July 18, 1862, vol. 168, 512-17, 553-54, 534-38, 541.

84. Richardson, Greatest Nation on Earth, 114; David Donald, Charles Sumner and the Coming of the Civil War(New York: Knopf, 1960), 45-69, 78-81; Edward L. Pierce, Memoir and Letters of Charles Sumner, vol. 4, 1860-1874 (Boston: Roberts Brothers, 1893), 48-49. See also Bigelow to Bright, February 16, 1863, add. 43390, vol. 8, John Bright Papers, British Library, London.

85. Clay to Bright, December 13, 1861, add. 43390, vol. 8, Bright Papers.

86. Stanford P. Gwin, "Slavery and English Polarity: The Persuasive Campaign of John Bright against English Recognition of the Confederate States of America," Southern Speech Communication Journal 49 (Summer 1984): 406-19; Roman J. Zorn, "John Bright and the British Attitude to the American Civil War," Mid America 38 (July 1956): 131-45; and Campbell, Unlikely Allies, 99-101, 166.

87. Daily Nerws, January 31, 1862. See also John Stuart Mill, "The Contest in America," Fraser's Magazine, February 1862, 12-13.

88. J. E. Cairnes, The Slave Power (London: Parker, Son, and Bourn, 1862), viii-ix, $2-14$.

89. Lorimer, "English Anti-Slavery Sentiment," 418.

90. Daily Neres, February 6, 1862.

91. Sheffield छ Rotherham Independent, February 27, 1862.

92. Glasgow Herald, May 26, 1862.

93. Glasgow Herald, June 11, 1862.

94. Heckman, "British Press Reaction"; Bright to Sumner, December 6, 1862, reel 27, Sumner Papers.

95. Howard Jones, "History and Mythology: The Crisis over British Intervention in the Civil War," in The Union, the Confederacy, and the Atlantic Rim, ed. Robert May (West Lafayette, Ind.: Purdue University Press, 1995), 30, 44; Ephraim D. Adams, Great Britain and the American Civil War, 2 vols. (New York: Longman, Greens and Co., 1925), 2: 427-29; and Kinley J. Brauer, "British Mediation and the American Civil War: A Reconsideration,” Journal of Southern History 38 (February 1972): 49-64.

96. Kinley J. Brauer, “The Slavery Problem in the Diplomacy of the American Civil War," Pacific Historical Review 41 (August 1977): 442; Robert Douthat Meade, Judah P. Benjamin: Confederate Statesman (New York: Oxford University Press, 1943), 265; Frank Merli and Theodore A. Wilson, "The British Cabinet and the Confederacy,"

60 JOURNAL OF THE CIVIL WAR ERA, VOLUME 3, ISSUE 1 
Maryland Historical Magazine 65 (Fall 1970): 239-62; Amos Khasigian, "Economic Factors and British Neutrality, 1861-1865," Historian 25 (August 1963): 453.

97. Wright and Wright, "English Opinion on Secession," 153.

98. Adams, Cobden Centennial, 2; Cobden to Bright, December 29, 1862, Cobden Papers, add. MS 43,652; Cobden to Sumner, February 13, 1863, reprinted in John Atkinson Hobson, The International Man (New York: Henry Holt, 1919), 368, 369; Bright to Field, quoted in Samuel Carter III, Cyrus Field: Man of Two Worlds (New York: Putnam, 1968), 204.

99. (London) Lady's Newspaper, February 8, 1862.

100. Parliamentary Debates, June 30, 1863, vol. 171, 1771-77.

101. J. M. Blackett, "Pressure from Without: African Americans, British Public Opinion, and Civil War Diplomacy," in May, Union, the Confederacy, and the Atlantic Rim, 69-100; Foner, British Labor, 67-78; Lorimer, "English Anti-Slavery Sentiment," 410-16.

102. Henry Ward Beecher, Patriotic Addresses in America and England, From 1850-1885, on Slavery, the Civil War, and the Development of Civil Liberty in the United States (New York: Fords, Howard, and Hulbert, 1888), 640, 529.

103. Papers Relating to Foreign Affairs, Accompanying the Annual Message of the President to the Second Session Thirty-Eighth Congress, pt. 1 (Washington, D.C.: GPO, 1865), 337 .

104. Leeds Mercury, January 25, 1864.

105. See for instance, Preston Guardian, February 27, 1864; York Herald, April 23, 1864.

106. Goldwin Smith, England and America: A Lecture, Delivered by Goldwin Smith, Before the Boston Fraternity during his Recent Visit to the United States (Manchester: A. Ireland and Co., 1865), 27-28. 